\title{
Changes in Eurozone Governance after the Crisis and the Issue of Growth
}

\author{
Daniele Schiliro \\ Correspondence: Daniele Schiliro, SEAM, University of Messina \& CRANEC, Università Cattolica di Milano, Italy
}

\author{
Received: January 11, 2014 Accepted: January 24, 2014 Available online: March 7, 2014 \\ doi:10.11114/ijsss.v2i2.317 \\ URL: http://dx.doi.org/10.11114/ijsss.v2i2.317
}

\begin{abstract}
The Eurozone countries are still seeking a way out of the crisis that has been affecting the European Monetary Union (EMU) since 2010. Sovereign debt crises, difficulties in the banking system and large current account imbalances have characterized the euro crisis, while several countries of the Eurozone have entered a phase of slow and even negative growth. All this has put at risk the sustainability of the EMU, leading to a climate of distrust surrounding the future of the single currency. The crisis of the Eurozone has shown that a sustainable currency union requires more governance because of the higher degree of economic, financial and fiscal spillovers between euro member countries. However, the crisis has led to significant changes in the institutional framework of the EMU and in the economic policies of the Eurozone, highlighting, above all, the role of the ECB. The present contribution analyses these changes in Eurozone governance and discusses whether they are the correct solutions to the crisis; in addition it focuses on the unresolved issue of growth in the peripheral Eurozone countries.
\end{abstract}

Keywords: Eurozone governance, current account imbalances, economic growth, ECB's monetary policy.

JEL classification: F15, F32, F33, H63, O40.

\section{Introduction}

The Eurozone countries are still seeking a way out of the crisis that has been affecting the European Monetary Union (EMU) since 2010. Sovereign debt crises, difficulties in the banking system and large account imbalances have characterized the economic conditions of the Eurozone, while several euro countries have entered a phase of slow and even negative growth. All this has put at risk the sustainability of the EMU, leading to a climate of distrust surrounding the future of the single currency. The eurozone crisis has shown that a sustainable currency union requires more governance because of the higher degree of economic, financial and fiscal spillovers between euro member countries; in addition, the global financial crisis has highlighted the lack of appropriate economic policy instruments to manage it. The Eurozone crisis has actually forced the European authorities and the heads of government of the member countries to try to reform the asymmetric and incomplete policy design of European Monetary Union. Of course, deep contrasts and divergent visions of the EMU and its institutions have come to light. The confrontation is essentially between those who want to commit to greater sovereignity transfers and resource pooling and those who advocate the primacy of national sovereignity and do not like a union that transfers resources. However, the crisis has led to significant changes in the institutional framework of the EMU and in the economic policies of the Eurozone, highlighting above all the extended role of the ECB. This article analyses these changes in Eurozone governance and discusses whether they are the correct solutions to the crisis; in addition, it focuses on the unresolved issue of growth in the peripheral Eurozone countries.

\section{Eurozone Governance before the Crisis}

European political leaders favoured the creation of a common currency as a first step towards deeper political integration. The initial impetus that led to European Monetary Union was political rather than economical. The main political reason for increased European integration was to enhance Europe's role in world affairs. The EMU has clearly proved to be an incomplete system, as it is based on a monetary union without fiscal union (von Hagen, Eichengreen, 1996). Monetary policy is managed at European level by the ECB, which has had a very narrow remit: namely, to ensure price stability. To achieve this objective, the ECB was given complete institutional independence ${ }^{1}$. However, the

\footnotetext{
${ }^{1}$ The independence of the ECB derives from Art. 282 of the TEU. For a survey on the literature regarding the Central Bank's independence and its performance see Pollard (1993).
} 
design of the EMU did not entrust the ECB with the function of lender of last resort, as is usually done for central Banks at a national level. Thus, the Eurozone has been deprived of an important stabilizer since its inception. At the same time, fiscal policy has remained under the direct responsibility of individual member states. This was a conscious political choice when the Maastricht Treaty was signed, in order not to create a fully-fledged economic union together with the monetary union, thus determining asymmetry in the institutional architecture (Schilirò, 2012). In addition, a major feature of the introduction of the single currency was the loss of exchange rate flexibility as an instrument of economic policy in the member countries. The no-bailout clause was a further relevant aspect of governance. The clause reflects the underlying principle of national fiscal responsibility on which the EMU was founded. This no-bailout clause, which precludes the sharing of liability for government debt across member States, was codified in Art. 125 of the Treaty on the Functioning of the European Union (TFEU) and by Art. 104, which rules out that the ECB or the Central Banks of the European System should provide direct credit to public authorities, defined in a comprehensive sense. Moreover, the Stability and Growth Pact (SGP) ${ }^{2}$ was introduced to establish specific constraints to individual member states and precise rules that restrict the actions of national governments in addition to the fiscal criteria of the Maastricht Treaty. The SGP was designed just to ensure a supranational budgetary discipline, so that short-sighted and opportunistic behaviors of the member states should be avoided or otherwise sanctioned.

Eurozone governance was therefore built on the assumption that it could be grounded on rules-based prevention only, and that there would be no need for crisis management (Pisani-Ferry, Sapir and Wolff, 2012, p.2). Since its inception, however, the institutional framework of the EMU has appeared incomplete and inadequate. In fact, governance has been based on decentralized policymaking, soft coordination and an insufficiently stringent enforcement of common rules (Schilirò, 2013). In addition, the European monitoring mechanism - managed by two institutions, the Ecofin and the Eurogroup $^{3}$ - focused exclusively on sovereign indebtedness, whereas other warning signals like wage increases, international competitiveness, etc. were ignored. Even the issue of financial stability was not included in EMU governance, while all the emphasis of the ECB was on price stability ${ }^{4}$. This was probably due to the prevailing idea that the convergence between national economies could be enforced, on one hand, by the market mechanism and on the other by European directives which, through best practices and benchmarking, would make the rules and the laws in the member countries homogeneous. Thus the institutional framework gave national policy wide discretion, creating an unstable environment, despite the Maastricth criteria and the Stability and Growth Pact.

At the same time, the governance of the EU/Eurozone relationship was relatively simple. The relevant provisions in the Eurozone could be designed as a self-contained set of rules, that interfered minimally with the general rules applicable to all EU members. Furthermore, in the light of the EMU's incomplete economic project, member states committed to common EU objectives and indicators under the heading of the Lisbon Strategy (2000-2010) (Bongardt, Torres, 2012). The EU's Lisbon Strategy approach was aimed at creating bottom-up support for reforms of the mixed economy so as to improve competitiveness and foster growth; it was driven by efficiency, but also by fairness and sustainability. However, given the different traditions and pathdependency of national institutions, policy instruments remained a national responsibility in the Lisbon Strategy, while member countries adopted the Open Method of Coordination (OMC) at EU level. As a result, the targets of the Lisbon strategy proved to be too ambitious and difficult to reach. Then, just before the euro crisis, the EU launched the Europe 2020 strategy, which seemed to set a shared long-term vision for all European countries. Again, however, given the current institutional set-up, there could be no illusion as to the responsibility and the capacity of national governments to implement this strategy. Yet the members of the European Union adopted an important innovation for the governance of EU, the European Semester. With this institutional innovation, the EU institutions (European Commission, European Parliament, UE Council) would aim to monitor national policies (i.e. budget policies) and macroeconomic imbalances beyond the simple regime of nominal rules ${ }^{5}$.

Actually, the Eurozone countries have not been homogenous - economically, institutionally or politically - since the outset of the EMU. Such heterogeneity includes not only different political attitudes, but also differences in economic

\footnotetext{
2 The SGP, established in Amsterdam on 17 June 1997, was later (March 2005) amended and some criteria were relaxed while procedural deadlines were extended.

${ }^{3}$ Ecofin makes decisions regarding the Excessive Deficit Procedure, Eurogroup supports Ecofin and keeps monitoring economic developments.

${ }^{4}$ In the Eurozone, capital markets ignored the lack of monetary independence of member country governments, so they regarded individual nations as capable of running large deficits.

${ }^{5}$ The European Semester is part of an attempt to link economic policies in the fields of structural adjustment (competitiveness policy, known as Europe 2020 strategy) and Eurozone commitments, for all member states with tougher oversight and sanctioning mechanisms. The first cycle of the European Semester began in 2011.
} 
structures, levels of competitiveness, fiscal traditions and social models (Feldstein, 2011). More specifically, in Europe, national labour markets are effectively separated by barriers of language, culture, union membership, and national social insurance systems. Also, the fiscal system and the monitoring of the banking system are managed at national level. With respect to the banking system in particular, the ECB did not have any direct role in banking supervision, unlike the Federal Reserve in the U.S. that serves as a bank regulator in setting the standards regarding the operations and activities of banks. The Maastricht Treaty, in fact, simply states that the ECB shall contribute to the smooth conduct of policies pursued by the competent authorities relating to the prudential supervision of credit institutions. (Art. 105). Thus responsibility for supervision of the banking system in the Eurozone so far has been established at national level.

This heterogeneity makes it more difficult to implement common rules. Institutional convergence is, therefore, important in reinforcing the economic union.

The European Union has shown a lack of political leadership and the European institutions appear rather tarnished. Institutions and politicians are especially concerned about the needs of the market while trying, at the same time, to reassure public opinion, often disappointing both. They generally do not have an updated vision in terms of medium- to long-term economic policy on which to anchor their decisions. As a matter of fact, European authorities have demonstrated that they lack an international alliance strategy, and are unable to identify sectoral priorities, tackle unemployment and face the problem of growth in peripheral Eurozone countries. In short, what seems to be missing is the ability to understand the economic and social reality of a Eurozone that is constantly changing.

\section{The Effects of the Eurozone Crisis}

The experience of the crisis has shown that the EMU has suffered from loose coordination and an ineffective sanction system, whereas the single currency had already deprived member governments of the monetary and exchange-rate instruments of macroeconomic management. Thus the Eurozone could not be shielded from the global financial storm. The imposition of a single monetary policy and the same base interest by the ECB to all member countries produced asymmetric impulses in their economies, with below - or above-average effects in terms of rates of growth and inflation, since the Eurozone was not an optimal currency area. Some member countries, in particular the 'PIIGS' (Portugal, Ireland, Italy, Greece and Spain) recorded a high deficit/GDP ratio and rising public debt; their banking systems were also in trouble. Furthermore, they recorded strong macroeconomic imbalances and loss of competitiveness (Schilirò, 2013). As a consequence, the economies of the PIIGS have become extremely vulnerable to potential disturbances in international financial markets, inducing capital flights, followed by liquidity crises and, in the case of Greece, by solvency crises. All this has determined deep concerns about the fiscal sustainability of the Eurozone.

The crisis of the Eurozone has highlighted several issues. First, it has emphasized a strong pursuit of national interests, which usually comes to the fore in times of crisis. At the same time, the crisis showed the weaknesses of the various European authorities, in primis the European Commission, which was unable to assume a central role in managing the unexpected economic and financial problems. Even the European Parliament has had a marginal role in formulating policies and economic decisions. But above all, European citizens have been made aware that their influence on European politics, expressed through voting, is practically non-existent and their feelings of frustration and impotence are particularly strong because of the crisis.

Moreover, the presence of large trade imbalances between euro countries has demonstrated that no mechanism exists to ensure the convergence of members' competitive positions. This stems from the fact that economic policies (spending and taxation, social policies, wage policies, etc.) remain firmly in the hands of the member governments that do not coordinate such policies. The Eurozone crisis has also shown the weaknesses of its banking system. Not only are banks not strong enough, but they are also connected with the sovereign debts. The fragility of banks and the relationship with the debt crisis has created the risk of bank failures in several euro member countries, and serious macroeconomic problems. In short, Eurozone governance has revealed the lack of a coordinated banking policy, which is crucial for crisis management. Finally, the critical situation of the crisis of EMU has challenged the relationship between the euro member countries and the European Union's non-euro countries.

But there is another relevant aspect of the crisis. Southern European countries like Greece, Portugal, Spain and Italy have had to face prolonged recessions ${ }^{6}$. Moreover, since the onset of the crisis, the weak growth in the European Union is making it much tougher for the hard-hit economies in southern Europe to recover competitiveness and regain control of their public finances (Darvas, Pisani, Wolff, 2013). These current difficulties of southern European countries matter politically to the extent that the EMU project is implicitly based on the idea of ever-deeper integration, which itself depends on the presence of some degree of convergence. Unfortunately, the crisis has led to a greater divergence of the

\footnotetext{
${ }^{6}$ According to De Grauwe and Ji (2013), the austerity measures that southern Eurozone countries have had to introduce since 2011 caused a double-dip recession.
} 
economies of the euro countries ${ }^{7}$. The divergence of the southern Eurozone countries, in particular, has proved to be structural and not just cyclical. This divergence regards productivity and growth. Therefore GDP per capita of the 17 Eurozone countries has evolved in very different directions. For example, in Greece between 2007 and 2013, GDP per capita decreased by 20 percentage points, reaching $68 \%$ of the European average.

Table 1 shows the real GDP growth rate of the 17 Eurozone countries.

Table 1. Real GDP growth rate

\begin{tabular}{llllllll}
\hline & \multicolumn{7}{c}{ Percentage change on previous year } \\
\hline Eurozone (17 countries) & 2007 & 2008 & 2009 & 2010 & 2011 & 2012 & $2013^{\wedge}$ \\
Austria & 3.0 & 0.4 & -4.4 & 2.0 & 1.6 & -0.7 & -0.4 \\
Belgium & 3.7 & 1.4 & -3.8 & 1.8 & 2.8 & 0.9 & 0.4 \\
Cyprus & 2.9 & 1.0 & -2.8 & 2.3 & 1.8 & -0.1 & 0.1 \\
Estonia & 5.1 & 3.6 & -1.9 & 1.3 & 0.4 & -2.4 & -8.7 \\
Finland & 7.5 & -4.2 & -14.1 & 2.6 & 9.6 & 3.9 & 1.3 \\
France & 5.3 & 0.3 & -8.5 & 3.4 & 2.7 & -0.8 & -0.6 \\
Germany & 2.3 & -0.1 & -3.1 & 1.7 & 2.0 & 0.0 & 0.2 \\
Greece & 3.3 & 1.1 & -5.1 & 4.0 & 3.3 & 0.7 & 0.5 \\
Ireland & 3.5 & -0.2 & -3.1 & -4.9 & -7.1 & -6.4 & -4.2 \\
Italy & 5.0 & -2.2 & -6.4 & -1.1 & 2.2 & 0.2 & 0.3 \\
Luxembourg & 1.7 & -1.2 & -5.5 & 1.7 & 0.5 & -2.5 & -1.8 \\
Malta & 6.6 & -0.7 & -5.6 & 3.1 & 1.9 & -0.2 & 1.9 \\
Netherlands & 4.1 & 3.9 & -2.8 & 4.0 & 1.6 & 0.9 & 1.8 \\
Portugal & 3.9 & 1.8 & -3.7 & 1.5 & 0.9 & -1.2 & -1.0 \\
Slovakia & 2.4 & 0.0 & -2.9 & 1.9 & -1.3 & -3.2 & -1.8 \\
Slovenia & 10.5 & 5.8 & -4.9 & 4.4 & 3.2 & 1.8 & 0.9 \\
Spain & 7.0 & 3.4 & -7.9 & 1.3 & 0.7 & -2.5 & -2.7 \\
\hline Source: E & 3.5 & 0.9 & -3.8 & -0.2 & 0.1 & -1.6 & -1.3 \\
\hline
\end{tabular}

Source: Eurostat (2013);^ forecast

All the Eurozone countries suffered because of the global crisis in 2009, when the growth rate of real GDP was negative throughout the Eurozone. Different countries, however, were affected to varying degrees. Estonia, Finland, Slovenia, Ireland and Italy suffered more than Portugal, Spain, Austria, Belgium and Cyprus. From 2010 onwards the situation changed and the divergence between countries increased as a consequence of the crisis. Countries such as Greece, Portugal, Spain and Italy but later also Slovenia, Cyprus and the Netherlands, entered recession. In some cases, such as Greece, Portugal, Spain and Italy, the fall in GDP has been so persistent as to prevent a recovery to the levels prior to the crisis, thus accentuating the divergence with the stronger countries (such as, for instance, Germany, Austria and Luxembourg). However, for the whole Eurozone, the real GDP growth rate continued to be negative in $2012(-0.7)$ and $2013(-0.4)$.

According to De Grauwe (2013) and Darvas, Pisani, Wolff, (2013), the lower GDP growth of the Eurozone countries after the global crisis can be seen as the consequence of more aggressive budgetary consolidation against the background of a still-weak private economy.

In addition, an impressive change has occurred in unemployment rates. In fact, in Greece, Portugal, Spain, Ireland, Cyprus and Italy the numbers of unemployed have reached very high levels, while countries such as Germany, Luxembourg and Austria have maintained low unemployment rates; thus, because of the crisis, the Eurozone countries have shown considerable dispersion in unemployment rates. The high unemployment rates in the peripheral countries

${ }^{7}$ Gough (2013) provides some evidence that the limited degree of convergence that existed by 1999 in the Eurozone was lost in 2007-2008. 
are the result of insufficient structural reforms of labour markets, which, in turn, have determined that unemployment assumes the role of the main shock absorber during the adjustment process. Moreover, the increased dispersion of unemployment rates across Eurozone countries, according to Estrada et al. (2013, p.31), is consistent with the hypothesis that the common currency in its initial design, jointly with the lack of country-specific monetary policies or stabilizing risk-sharing devices, may have been a factor behind the large differences in unemployment rates.

Lastly, imbalances in external accounts of the peripheral countries have expanded due to the crisis, revealing, for the debtor countries, a gap in the levels of competitiveness, with obvious implications for growth. At the same time, credit growth has been weak in southern European economies and lending conditions have remained tight, whilst capital flows in the Eurozone are related to the current account imbalances and differences in levels of competitiveness. It seems clear that the crisis has certainly worsened the economic conditions of the peripheral countries, since the deficit countries, almost exclusively, had to bear the burden of the adjustments to the imbalances. The causes of the large current account imbalances in many peripheral countries may in part be attributed to their higher domestic demand growth in the years before and during the crisis and diverging unit cost levels. Therefore, addressing the external competitiveness of peripheral countries is essential to limit intra-Eurozone imbalances and to support growth in southern European countries.

Under a common currency, competitiveness has to come by changing costs, such as lowering salaries, or improving productivity through innovation and investment, but in political terms, of course, lowering production costs is very challenging. However, Estrada et. al. (2013), through their empirical analysis, suggest that a comprehensive strategy aimed at reducing the large current account deficits of some of the Eurozone countries should include, besides a reduction in wages, structural reforms that help enhance relevant non-price competitiveness factors ${ }^{8}$, since external adjustment requires continued gains in competitiveness. In particular, they support a strategy aiming to strengthen technological readiness (i.e. the quality of a country's business networks and supporting industries) and innovation capabilities through innovation and $R \& D$ effort.

Another aspect of these current account imbalances between the northern countries of the Eurozone and the southern countries is that these imbalances have contributed to the accumulation of a large stock of foreign debt, whereas capital flows have not led to a more efficient allocation. In fact, the flows of foreign capital have ceased to finance productive investment; at the same time too much investment has gone to real estate and other projects with low returns in terms of potential GDP growth ${ }^{9}$. Meanwhile, the manufacturing sector has declined significantly in the southern European countries.

These capital flows led the system towards instability and sovereign default. According to Hughes Hallett and Martinez Oliva (2013), public intervention by loans, bailout haircuts, liquidity injections and by the simple replacement of private with public creditors could only temporarily help to stave off a breakdown in the system.

However, the current account deficit of the peripheral Eurozone countries led to the ECB's intervention to prevent a meltdown of the EMU, with the aim of giving the countries more time to implement the structural reforms they needed.

\section{The Path to a New Governance of EMU.}

The answer of the European authorities and the heads of government of the Eurozone countries to the crisis of the peripheral economies and, more generally, to the crisis of the Eurozone, was to try to enhance the governance of the EMU and to reinforce cooperation in economic and social policies. They recognize that the interaction of monetary policy with a broader EU governance as well as the need for coordinated actions are essential for a successful response to the crisis. As a consequence, bailout programmes have been implemented since the spring of 2010. Such programmes consist of financial aid provided by the EU together with the IMF to countries on the verge of insolvency, like Greece ${ }^{10}$,

\footnotetext{
${ }^{8}$ Estrada, Galì and Lopez-Salido use a comprehensive set of variables (besides prices and wages) to measure competitiveness, usually referred to as the Global Competitiveness Index (CGI), composed of twelve 'pillars'. These 'pillars' are: institutions; infrastructure, macroeconomic environment, health and primary education, higher education and training; goods market efficiency, labor market efficiency, financial market development, technological readiness, market size, business sophistication; innovation.

${ }^{9}$ In particular, excessive housing booms have distorted prices and wages and led to the misallocation of capital in a number of EU countries (Darvas, Pisani-Ferry, Wolff, 2013).

${ }^{10}$ In May 2010 and, later, in February 2012, Greece was granted bailout loans by the EU and the IMF. In the second case, the bailout deal included, for the first time, a debt restructure agreement with the private holders of Greek government bonds to 'voluntarily' accept a bond swap with a 53.5\% nominal write-off. The debt write-off was of $€ 107$ billion, and caused the Greek debt level to fall from roughly €350bn to €240bn in March 2012.
} 
or in financial difficulties like Ireland and Portugal and, more recently, Spain and Cyprus. These bailouts have exposed long-standing fears about an absence of democratic legitimacy in EMU governance (Schilirò, 2012).

Another response was the creation of the European Financial Stability Facility (EFSF) in May 2010 aimed at ensuring financial stability in Europe. The EFSF provided emergency financing until 1 July 2013. From October 2102, the European Stability Mechanism (ESM) became operative: a permanent rescue mechanism with a maximum lending capacity of $€ 500$ billion that provides financial assistance to Eurozone countries in financial difficulty, replacing the existing temporary funding programmes such as EFSF and EFSM (the European Financial Stabilization Mechanism) ${ }^{11}$. Since July 2013, the ESM has been the sole and permanent mechanism for responding to new requests for financial assistance by Eurozone member countries. The decisions of the ESM, however, are subject to the veto power of any country member. This veto power by any country is likely to make the decision-making process unworkable during crises (De Grauwe, 2013). Another criticism of the ESM, voiced by several observers, including De Grauwe, is that the financial capacity of the fund to tackle the eurozone crisis is inadequate.

At the same time, the ECB, whose strategic role in the multi-level governance context of the EMU has been particularly relevant, has made every effort to preserve price stability and, above all, to guarantee the sustainability of the monetary union, engaging in extraordinary monetary policies, beyond standard monetary tools ${ }^{12}$. At the outset of the sovereign crisis in 2010, the ECB extended its role beyond its price stability mandate. The ECB adopted wide-ranging measures to support financial stability and repair the monetary transmission mechanism by providing banks with ample liquidity under revised collateral rules and by launching two government bond purchasing programmes ${ }^{13}$. Firstly, it adopted a measure, called 'Securities Market Program' (SMP), which aimed at providing liquidity to the Eurosystem, in order to lower the spreads on sovereign bonds and, therefore, reduce volatility in the financial markets ${ }^{14}$. However, this program was not a great success, since the ECB announced that it was limited in size and time. Later, in December 2011, the ECB launched a Longer Term Refinancing Operation (LTRO), a program of granting low-interest loans for a term of 3 years (36 months) and 1\% interest to European banks, and accepting loans from the portfolio of the banks as collateral ${ }^{15}$. This is an unconventional measure taken by the ECB to offset the lack of liquidity that has occurred in the credit market, as during the crisis the ECB had to face a dysfunctional interbank market. Actually, the ECB started to act and provided massive liquidity support to the banking systems of EMU countries just when the banks were at risk, not when sovereigns were involved (De Grauwe, 2013). The result of LTRO was that the amounts of liquidity provided was taken up, in particular, by banks in countries under stress, while a large proportion of the total liquidity increase was parked in the ECB's deposit facility mainly by the northern European banks. So LTRO did not improve the credit conditions of the non-financial sector. At the same time, the evidence seems to show that it did not address bank solvency problems. The LTRO, however, led to a decrease in the interest rates on government bonds of the PIIGS with an increase of the holdings of government securities in the banking systems of the PIIGS (Pisani-Ferry, Wolff, 2012). In addition, the ESM Treaty has assigned a new task to the ECB, since it has formalised the ECB's function of covering the whole process of granting and monitoring financial assistance programmes. But, as Darvas and Melter (2013) point out, the ECB's participation in the design and monitoring of financial assistance programmes creates potential conflicts of interest with the other mandates of the ECB.

Since the European authorities were convinced that financial markets were able to guarantee the task of stabilizing the economies in Europe and to ensure their integration, they based their strategy on uniformity. Thus, the new governance has been devised through various tools of intervention: 'Six pack', 'Fiscal Compact', 'Two pack', all geared towards a logic of austerity. In addition, all these measures, with their disciplinary mechanisms and their sanctions, together with the European Semester, were aimed to relieve the ECB of its fears of moral hazard risk, since liquidity provisions by the

${ }^{11}$ In April 2013, the ESM approved two Financial Assistance Facility Agreement (FAFA) programs, up to $€ 100 \mathrm{bn}$ as a recapitalisation package of Spanish banks, and €9bn in disbursements for Cyprus for a sovereign debt bailout program and a financial sector recapitalization program.

${ }^{12}$ On the use of non-standard measures of monetary policy see Cúrdia and Woodford (2011).

${ }^{13}$ Darvas, Merler (2013, p.2).

${ }^{14}$ The SMP was temporary and it was mainly active during two periods. The first period started after the ECB Governing Council meeting on May 14, 2010 and lasted until the week of July 9, 2010. The second period began in August 2011 and lasted until January 2012. The creation of the SMP was closely related to the Greek debt crisis, but it was also helpful for the sovereign debts of Spain and Italy.

${ }^{15}$ This LTRO is primarily designed to provide greater bank liquidity, but it should also lower sovereign yields since euro area countries can use their own sovereign debt as collateral, which, in turn, increases demand for the bonds and lowers yields. 
central bank tend to create moral hazard problems. The EU 'Six-pack', in particular, was decided earlier in September 2010 and related to regulations and guidelines regarding fiscal policy and macroeconomic imbalances. The reforms contained in the 'Six-pack' were based on the Lisbon Treaty, perpetuating the distinction between euro countries and non-euro countries. Later, in March 2011 the Ecofin Council agreed to give content to the 'Six-pack' with the agreement named 'Pact for the euro' which tried to achieve a better economic policy coordination that would lead to a higher degree of convergence. Although the 'Pact for the euro' pursued specific strategies, these were not compulsory. It follows that the choice of the specific policy actions, necessary to achieve the common objectives, remained under the responsibility of the national governments of member countries.

In the first two years of the Eurozone crisis (2010 and 2011), the European authorities pursued the method of small steps, following the strategy of muddling through, instead of adopting radical decisions. The markets and many observers (economists, opinion makers, businessmen, etc.) felt that the European authorities did not yet have governance mechanisms capable of implementing adequate solutions. In addition, member countries seemed unwilling to act against the crisis. Particularly, the virtuous members states (with Germany taking the role of leader) did not want to pay for those in difficulty, while the weaker countries were not pleased with the sacrifices that Europe asked of them.

On 2nd March 2012 the 'Fiscal Compact', namely the Treaty on Stability, Coordination and Governance in the Economic and Monetary Union (TSCG), was signed by member states of the European Union, except the Czech Republic and the United Kingdom. This is an intergovernmental agreement ${ }^{16}$ and a major step in the direction of greater austerity and control of national budgets. The 'Fiscal Compact' requires contracting parties to ensure convergence towards the country-specific medium-term objective (MTO), as defined in the SGP. Moreover, correction mechanisms should ensure automatic action to be undertaken in case of deviation from the MTO or the adjustment path towards it, with escape clauses for exceptional circumstances. One important aspect of the TSCG is that these budget rules are implemented in national law through provisions of 'binding force and permanent character, preferably constitutional'. Consequently, democratic politics at the national level will continue to have a fundamental influence in EU affairs (Glencross, 2013). However, the TSCG also reinforces surveillance and coordination of economic policies and provides for Euro Summits to take place at least twice a year: a new aspect of economic governance in the Eurozone.

Another important tool of the new governance is the 'Two pack', which entered into force in June 2013. This is a package of rules that gives new powers to the EU Commission including the right to impose changes to the financial laws of the Eurozone member states. Essentially, it aims at further strengthening the surveillance mechanisms in the Eurozone. Common budgetary rules at the national level will be monitored by independent institutions. As part of a common budgetary timeline, Eurozone member states will submit their draft budgetary plan for the following year to the Commission and the Eurogroup before 15 October, along with the independent macro-economic forecast on which they are based ${ }^{17}$. By 30 November the Commission will analyze the draft budgetary plan and give its opinion. If it considers that member states do not comply with the constraints of the Stability Pact, the Commission will ask governments to change them. The 'Two pack' has strong political implications, as it becomes an additional tool for limiting the sovereignty of individual states, in the name of implementing procedures for the convergence of the fiscal and economic policies of Eurozone countries.

This set of tools represents a form of top-down economic management of the crisis which constitutes a historic turning point for European integration, since the EU has never been implicated to such an extent in deciding national tax and spending policies (Glencross, 2013).

In this context, the ECB has reinforced its role in the governance of the euro. Thus in August 2012, the ECB made the simple announcement that it had launched an innovative purchasing program called 'Outright Monetary Transactions' (OMT), a non-standard measure of monetary policy under which it makes purchases in secondary sovereign bond markets, under strict conditions, of bonds issued by Eurozone member states ${ }^{18}$. Under this program, the ECB would consider buying, without announcing any preset limits, government bonds with remaining maturities of between one and three years, only if the country concerned had first sought assistance from Europe's bailout fund (i.e. ESM) and had adopted an economic adjustment plan endorsed by the Eurozone, and judged suitable by the ECB ${ }^{19}$. Thus, the ECB

\footnotetext{
${ }^{16}$ An intergovernmental agreement is not EU law.

17 This regulation, introduced in June 2013, therefore complements the preventive arm of the SGP.

${ }^{18}$ The technical framework of these operations was formulated on 6 September 2012 while, on the same date, the ECB's Securities Markets Program (SMP) was terminated.

${ }^{19}$ In other words, this condition may subject countries in financial difficulty to an additional austerity program.
} 
becomes involved in the monitoring of the budgetary policies of the euro member countries. In this way it gets involved in highly political decisions which may be at odds with its role of independence. The OMT program is not temporary and makes the ECB more similar to a lender of last resort ${ }^{20}$, since it allows the debtors in difficulty ${ }^{21}$ to be refinanced. In fact, without the ECB's lender of last resort function, the governments of EMU countries were not able to guarantee that the cash would always be available to roll over government debt (De Grauwe, 2013). In addition, by means of the OMT program the ECB has begun to assume a major coordinating and supervisory role, typical of a lender of last resort. This decision made by the ECB in August 2012 to commit itself to unlimited support of the government bond markets has been considered a game changer in the Eurozone with dramatic effect, according to De Grauwe and Ji (2013). Actually, the program has been widely credited with restoring calm to Eurozone sovereign debt markets, and helping to reduce borrowing costs in peripheral countries, such as, for instance, Spain and Italy, by providing an effective backstop against the risk of the monetary union breaking apart. Yet, the OMT program has been heavily criticized in Germany (especially by the Bundesbank) as potentially exposing Europe's largest economy to severe financial risks without its electorate having any say. In short, there is a concern that the ECB is setting the wrong incentives for both banks and governments. However, the set of standard and non-standard measures taken by the ECB, including the expansion of its balance sheet over 2.5 trillion euros, has led the Bank of Frankfurt to expand its mandate to include the preservation of the stability of the financial system.

Last but not least, a major change in the ECB's role is due the decision to entrust it with fundamental supervisory responsibilities within the framework of the Single Supervisory Mechanism (SSM), which is the first element of the European Banking Union (Darvas, Malter, 2013). The legal basis for this is provided by Art. 127 of the TFEU ${ }^{22}$. For this reason, since spring 2012, the Ecofin. together with the ECB, has proposed the creation of the SSM, a financial supervision system, which comprises the ECB and the national competent authorities. Thus in December 2012, with this authority entrusted to the ECB, EU leaders chose to move towards the centralization of bank supervision across Eurozone countries. The participating countries are the euro member countries and also those countries who have decided to enter into close cooperation with the single supervisory mechanism. The main aims of SSM are to ensure the safety and soundness of the European banking system, to increase financial integration and stability in Europe and to start reversing the vicious circle between banks and sovereign credit. The SSM implies that the ECB will assume its new banking supervision responsibilities in autumn 2014, a year after the approval of regulations on 15 October 2013. In order to make its new function work properly, however, the ECB must establishes itself as a credible regulatory body that ensures that banks in the Eurozone are adequately capitalised. Some observers, like Veron (2013), point out that this new task of the ECB requires a transitional arrangement, which should focus on the combination of balance sheet assessment of the banks led by the ECB to reduce the uncertainty and the restructuring of weaker banks that is needed for a successful handover of supervisory authority in 2014.

On 19 December 2013, Ecofin reached an agreement and approved the second phase of the European Banking Union. This second phase mainly consists in the ECB's supervision of the banks and in the single resolution mechanism (SRM) (through rescue or liquidation) of the possible banking crisis. The resolution system is based on the single board of resolution which has the responsibility of rescuing or closing an ailing bank. Of course, the weight of Germany has been decisive in the design of the mechanism. In particular, the German government has ensured that the European Commission does not have a central role in this resolution system and that the ESM, which is funded with common resources by member countries, does not serve to help the banks. However, it is important that the ECB's new role of common banking supervision from 2014 on does not interfere with its monetary policy mandate. This requires a clear institutional separation between monetary policy and its supervisory function.

In conclusion, notwithstanding the extension of tasks given to the ECB and the importance of its role of lender of last resort in times of market panic, the problems regarding the fundamentals of peripheral Eurozone countries remain unresolved, especially the current account imbalances and the problem of growth. I share the view ${ }^{23}$ that the recipe of fiscal austerity plus internal devaluation in the periphery won't work because there is no offsetting demand stimulus

${ }^{20}$ The notion of lender of last resort during a credit crunch is still related to Walter Bagehot's Dictum (1873) that central banks should lend early and without limits to solvent firms, against good collateral, and at 'high rates.'

${ }^{21}$ The lender of last resort function of the central bank, however, comes at the price of increased moral hazard.

22 "The Council, acting by means of regulations in accordance with a special legislative procedure, may unanimously, and after consulting the European Parliament and the European Central Bank, confer specific tasks upon the European Central Bank concerning policies relating to the prudential supervision of credit institutions and other financial institutions with the exception of insurance undertakings". Art. 127 (6) TFEU.

${ }^{23}$ See Darvas, Pisani-Ferri and Wolff (2013), De Grauwe (2013), Ubide (2013). 
from the Eurozone or the rest of the world and because it assumes that the economic infrastructure of the euro is basically adequate and does not require any changes. Thus, the crisis in the Eurozone remains a political crisis with deep economic consequences. The OMT program has perhaps saved the euro by reducing national borrowing costs and restoring a situation of greater stability in financial markets, but it has not solved the fundamental economic and political issues of European Monetary Union and its sustainability.

\section{Conclusions}

In this article I have highlighted the significant changes in Eurozone governance, stressing the increasing extended role of ECB and some of its conflicting tasks. I have also examined the remedies put in place by the European authorities to overcome the crisis and their flaws. One central aspect of my analysis is that the impact of the crisis has revealed that member states have not taken sufficiently into account the negative spillover from the monetary and financial part of the EMU over their economic sphere and viceversa. At the same time, the crisis has highlighted that a monetary union sets additional demands on the economic sphere in order to be sustainable. Moreover, an economic and monetary union requires a high degree of cooperation between the member countries. At the time of its inception, the EMU and its governance were considered independent from the process of European political integration. The crisis highlighted that the EMU cannot survive without a political union since the Eurozone has insufficient compensation mechanisms. It is, in fact, characterized by, among other things, an absence of automatic fiscal transfers, lower labour mobility and wage flexibility, and less integrated financial markets.

The crisis, however, is still present in the Eurozone. For over three years European authorities and political leaders have been promising to do whatever is needed to save the monetary union and its currency, but many problems remain unsolved. The Eurozone is therefore characterized by strong imbalances, unemployment and the anemic growth of southern countries; in particular these countries suffer from low productivity, lack of competitiveness, protracted deleveraging and a weak banking sector. On the other hand, Eurozone governance, although recently more effective, having undergone important changes, appears still not fully adequate to address these imbalances and to stimulate growth. The recent experience of crisis management, where each member state fights alone against its disequilibrium in sovereign debt, current account balance, unemployment, competitiveness or credit conditions, without taking sufficiently into account the spillover effects and the interdependence between the Eurozone countries, have demonstrated the failure of this policy strategy. Moreover, the sovereign debt crisis of the Eurozone highlights not only problems of democratic legitimacy for introducing reforms, but also strong critical points in economic and political solidarity. Thus the European crisis seems to be the result of collateral damage from political disagreements over the real purpose of the EMU and European integration (Hughes Hallett, Martinez Oliva, 2013, p.3).

A true and effective change of governance demands greater European integration, where not only the European Central Bank needs to become lender of last resort, as the latest monetary policy tools seem to delineate, but a central fiscal entity is necessary at European level which requires a transfer of sovereignty from the individual member states. In addition, there should be a different relationship between the member countries of the Eurozone, bestowing on the Commission the role of coordinator and of third party. Lastly, the European Parliament should obtain centrality and the European citizens with their vote should weigh more on the decisions taken in Brussels.

A more stable and comprehensive solution for the governance of the monetary union requires a deep change at institutional level, where the European institutions must become capable of implementing the economic policy for the whole Eurozone.

This deep change in governance at institutional level should be established in the medium term on a robust legal basis with a change in the European treaties. This is a possible way out of the crisis, even if it is not simple to achieve and to implement because of the heterogeneity of the member states and of their strong divergent economic and political interests. However, such a solution would be a step forward compared to the EMU's current hybrid and asymmetrical institutional architecture. In fact, it is just by following this complex strategy, which requires a more cooperative and supportive behavior between member states, that it is possible to restore credibility in the Eurozone, create a stable macroeconomic environment, and stimulate economic growth in the peripheral countries so to overcome this structural and lasting crisis.

\section{References}

Bagehot, W. (1873). Lombard Street: A Description of the Money Market. London, King; reprinted New York, Wiley, 1999.

Bongardt, A., \& Torres, F. (2012). The Lisbon Strategy, in Jones, E., Menon, A., Weatherill, S. (eds.), The Handbook on the European Union, Oxford, Oxford University Press, pp. 469-483.

Cúrdia, V. Woodford M. (2011). The Central Bank balance sheet as an instrument of monetary policy, Journal of 
Monetary Economics, 58(1), 54-79. http://dx.doi.org/10.1016/j.jmoneco.2010.09.011

Darvas, Z., \& Merler, S. (2013). The European Central Bank in the age of banking union, Bruegel, Bruegel Policy Contribution, issue 2013/03, October.

Darvas, Z., Pisany-Ferry, J., \& Sapir, A. (2011). A comprehensive approach to the euro-area debt crisis. Bruegel, Bruegel Policy Brief, n.2, February.

Darvas, Z., Pisany-Ferry, J., \& Wolff, G. (2013). Europe's growth problem (and what to do about it). Bruegel, Bruegel Policy Brief, n.3, April.

De Grauwe, P. (2013). Design failures in the Eurozone: can they be fixed?, LEQS Paper No.57, February.

De Grauwe, P., Ji, Y. (2013). Panic-driven austerity in the Eurozone and its implications, VoxEU.org, February.

Estrada, A., Galì, J., \& Lopez-Salido, D. (2013). Patterns of convergence and divergence in the euro area, Barcelona GSE Working Paper, n.722, October.

Eurostat, 2013. Real GDP Growth Rates, Brussels, European Commission. http://epp.eurostat.ec.europa.eu/portal/page/portal/eurostat/home/

Feldstein, M. S. (2011). The euro and European economic conditions, NBER Working Paper No. 17617, November.

Glencross, A. (2013). The EU response to the eurozone crisis: democratic contestation and new fault lines in European integration, Europa-Kolleg Hamburg Discussion Paper, n.3/13, July.

Gough, J. (2013). The Eurozone. Whatever happened to convergence? World Economics, 14(2), 53-72. April-June.

Hughes, H., A., \& Martinez, O., J. C. (2013). The importance of trade and capital imbalances in European debt crisis, Peterson Institute for International Economics, Working paper, n.1, January.

Pisani-Ferry, J., \& Wolff, G.B. (2012). Propping up Europe?, Bruegel, Bruegel Policy Contribution, issue 2012/07, April.

Pisani-Ferry, J., Sapir, A., \& Wolff, G. B. (2012). The messy rebuilding of Europe, Bruegel, Bruegel Policy Brief, issue 2012/01, March.

Pollard, P. S. (1993). Central Bank independence and economic performance, Federal Reserve Bank of St. Louis Review, 75(4), 21-36.

Schilirò, D. (2012). A new governance for EMU and the economic policy framework, MPRA Paper 47454, University Library of Munich, Germany.

Schilirò, D. (2013). The crisis of euro's governance: institutional aspects and policy issues, in R.Mirdala (ed.), Financial Aspects of Recent Trends in the Global Economy, vol.II, Craiova, Asers Publishing, pp. 150-163.

Ubide, A. (2013). Reengineering EMU for an uncertain world, Peterson Institute for International Economics, Policy Brief, n.13-4, February.

Veron, N. (2013). A realistic bridge towards European banking union, Peterson Institute for International Economics, Policy Brief, n.13-17, June.

von Hagen, J. \& Eichengreen, B. (1996). Federalism, fiscal restraints, and European Monetary Union, American Economic Review, 86(2), 134-138.

\section{(cc) EY}

This work is licensed under a Creative Commons Attribution 3.0 License. 